$10-19-2017$

\title{
America’s Machiavellian: Gouverneur Morris at The Constitutional Convention
}

John Patrick Coby

Smith College, pcoby@smith.edu

Follow this and additional works at: https://scholarworks.smith.edu/gov_facpubs

Part of the Political Science Commons

\section{Recommended Citation}

Coby, John Patrick, "America’s Machiavellian: Gouverneur Morris at The Constitutional Convention" (2017). Government: Faculty Publications, Smith College, Northampton, MA.

https://scholarworks.smith.edu/gov_facpubs/4 
“America's Machiavellian: Gouverneur Morris at The Constitutional Convention"

John Patrick Coby Professor of Government

Smith College

pcoby@smith.edu 


\begin{abstract}
While generally a steady ally of James Madison and the nationalists, Gouverneur Morris, delegate from Pennsylvania, worked from a different conception of republican politics. Morris' republicanism was more old than new, relying on the divided sovereignty of a mixed regime to protect the rights of citizens and minorities. This conception, the paper argues, bears the stamp of Machiavelli, especially regarding the relationship of the classes and the role of the executive. Like Machiavelli-but unlike Madison-Morris wanted to underscore society's class divisions, which he saw as constant, organizing the representatives of rich and poor into two distinct, and hostile, chambers of the legislature. And like Machiavelli, whose "civil prince" was the champion of the people, Morris' executive was to be the "guardian of the people" and the "guardian of liberty." A final section of the paper looks at Morris' personality and Convention maneuverings, some aspects of which are suggestive of Machiavelli. A conclusion reviews Morris' three main contributions to the Constitution.
\end{abstract}




\section{“America's Machiavellian: Gouverneur Morris at the Constitutional Convention”}

The American Constitution, as represented by the Federalist Papers, is an instrument fully capable of remedying the ills most incident to republican government. The optimism expressed by Publius, in papers 9, 10, and 51 especially, stemmed from the belief that the Constitution incorporated the discoveries of a new science of politics. Included among these discoveries were separation of powers, bicameralism, representation, enlargement of the sphere, and compound government, or federalism; while included among the ills were oppression by the government and tyranny by the majority. The new science provided for ordered liberty and moderate policies because government would be invigorated and yet checked, and because majorities would prevail electorally and yet be limited in their ambitions. The extended size of the republic guaranteed a multiplicity of interests, which in turn guaranteed that no interest by itself would constitute a natural and permanent majority. Majorities instead would be constructed and temporary alliances, coalitions of minor parties and shifting interests apt to fly apart the moment policy became unjust or too narrowly self-regarding. The extended sphere, operating as an "invisible hand" of sorts, would cause majorities to temper their demands in order to hold together the coalitions on which they stood; and the institutions and practices of the new science, called "auxiliary precautions," would oblige government to proceed slowly and rule by consensus. Mild and considerate politics was the expected result, even though the people were engaged and no power outside the people, such as a king, looked after the common good.

The Constitution, however, may not be exactly as the Federalist describes, if only because the parties responsible for drafting the Constitution were not all devotees of the new science of politics. Some delegates to the Philadelphia Convention preferred a weak and dependent executive inconsistent with the doctrine of separated powers (e.g., Roger Sherman); or preferred a 
unicameral in place of a bicameral legislature (e.g., Luther Martin); or wanted representatives to reflect public opinion rather than refine and check it (e.g., George Mason); or accepted enlargement of the sphere on condition that the union continue as a confederation of small republics (e.g., John Lansing); or sought instead a consolidated union with a single, central government, using states as administrative agents (e.g., George Read). Much of the opposition came from delegates of the states'-rights persuasion, persons who subsequently joined the Antifederalist cause during the Ratification debates. Opposition from the nationalist delegates tended to be ad hoc in character, like rejection of a national veto over state laws (e.g., John Rutledge) or of a council of revision consisting of the executive and members of the judiciary (e.g., Rufus King). But there was one delegate on the nationalist side who mounted a more systematic challenge to the new science. This was Gouverneur Morris of Pennsylvania. Morris, it here is argued, spoke for an older science of politics, a theory of republicanism, with roots in Machiavelli, that trusted the defense of liberty to a mixed regime composed of fixed social orders, presided over by a strong executive. ${ }^{1}$

\footnotetext{
NOTES

${ }^{1}$ The new science of politics, according to Federalist 51, acknowledges the sovereignty of the people ("fountain of authority”), while requiring that it operate through constitutional structures that afford protection for minority rights. The old science of politics divides sovereignty across the social orders of a mixed regime, protecting minority rights by incorporating "a will in the community independent of the majority." (See Gordon Wood, The Creation of the American Republic, 1776-1787 [New York: Norton, 1969], 554.) Machiavelli embraces the mixed regime (Discourses on Livy 1.2.2-5) and for that reason is regarded an old republican. In other respects, he is new, if not himself the progenitor of the new science (see Leo Strauss, Thoughts on Machiavelli [Seattle: University of Washington Press, 1958], 61, 83, 232): for example, he encourages acquisition (Prince 3) in opposition to the Classical-Christian tradition that encourages moderation. But even here, more old than new is Machiavelli, insofar as acquisition for him
} 


\section{Re-Enter Morris}

"We are now at a full stop," declared a disconsolate Roger Sherman, delegate from Connecticut. The Convention had just split 5-5-1 (ayes, nays, divided) on the question of state suffrage in the upper house. A previous vote taken on June 11 had favored suffrage proportionate to population; ${ }^{2}$ but opinion was turning, and on July 2 the forces of equal state suffrage - mostly small-state delegates - managed to produce this tie.

July 2 was also the day when Gouverneur Morris, missing since May 31, returned to the Convention. Morris was a New York native, born into a prosperous political family, who for the last decade had lived in Pennsylvania. He was a big man, something over six feet tall (in an era

depends on war and conquest, whereas for his modern disciples (e.g., Montesquieu), it depends on commerce and industry. (See J. Patrick Coby, Machiavelli's Romans: Liberty and Greatness in the Discourse on Livy [Lantham, MD: Lexington Books, 1999], 146, 277-84; and J. Patrick Coby, Machiavelli’s Philanthropy," History of Political Thought 20 [1999]: 618-26. In these works I argue, in partial disagreement with Strauss, Harvey Mansfield [e.g., Machiavelli's New Modes and Orders: A Study of the Discourses on Livy (Ithaca: Cornell University Press, 1979); Machiavelli's Virtue (Chicago: University of Chicago Press, 1996)], and some others that Machiavelli is an ancient more than he is a modern, urging adoption of Roman modes of governance and conquest; and that his originalityhis "new modes and orders" and his "path as yet untrodden by anyone" [D.1.Preface.1]—consist mainly of reforms of Rome's constitution toward the end of better controlling and energizing executive power, in the first instance; and, in the second, of a propagandistic use of history and a writing style designed to teach the art of prudence [Machiavelli's Romans, 195-223].) I do not mean to suggest that Morris rejected the institutions of the new science; I only suggest that he questioned their sufficiency in safeguarding liberty.

${ }^{2}$ By a vote of 6-5, the Convention on June 11 approved "some equitable ratio of representation"-i.e., suffrage proportionate to population - for the upper house; and on June 19, by a vote of 7-3-1, the Convention adopted the revised Virginia Plan, which made representation for the upper house proportional (Resolution 8). Votes taken on June 11 (7-3-1), June 19 (7-3-1), and June 29 (6-4-1) applied proportionality to the lower house. 
when the average male height was 5'6") and as a youth nicknamed Tall Boy. He would have towered above all but a few of the delegates; and if he rambled about the room while speaking, he would have entranced the members — or irritated them-with the recurrent thumping of his wooden peg leg. An unusual individual, to be sure, whom a fellow delegate described as a wit and a genius, "conspicuous and flourishing in public debate," charming, captivating, and a pleasure to hear; but also "fickle and inconstant—never pursuing one train of thinking—nor ever regular."3

Morris took the floor; and being neither diffident nor apologetic about his month-long absence, he immediately set about accusing the Convention of having misconstrued the basic nature of an upper house, whether conceived as a body representing states or representing people. For in fact, the purpose of an upper house, he averred, was to represent wealth. So vital was this function, and so uncertain of success, that the upper house, or senate, was to be constructed as a set-aside for the propertied few. The rationale was what truly amazed, however-namely, that the wealthy must be given a chamber of their own lest they infiltrate and dominate the chamber of the people. "The proper security against them [the wealthy]," said Morris, "is to form them into a

\footnotetext{
${ }^{3}$ William Pierce of Georgia wrote brief character sketches of the Convention delegates. These are found in volume 3 of Max Farrand, ed., The Records of the Federal Convention of 1787, rev. ed., 4 vols. (New Haven: Yale University Press, 1966, 1987), 87-97. Volumes 1 and 2 of Farrand contain the notes taken by Convention delegates (excluding those taken by John Lansing, in the fourth-volume supplement edited by James Hutson, 1987). Citations of Convention debates are identified by date, volume, and page number (e.g., May 31, 1:48) and are kept in the text. References to volume 3, which contains Convention related materials, like the Pierce sketches, show the editor's name, the book's title, volume number, and page number (e.g., Farrand, Federal Convention, 3:106) and are placed in the footnotes. Misspellings of proper names are corrected; otherwise original spellings are retained. Original punctuation is also retained, except in cases where it interferes with comprehension. Full words usually replace abbreviations.
} 
separate interest" (1:512). An aristocratic/oligarchic institution, characteristic of mixed regimes, would deliver a partially democratic result, he seemed to promise.

Morris was not the only Convention delegate promoting the representation of property. The Virginia Plan, introduced by Virginia governor Edmund Randolph at the start of the proceedings and organizing debate thereafter, was open to the idea (Resolution 2); and assorted delegates, the South Carolinians especially, returned to it repeatedly. Nor was Morris the only person at the time to propose the sequestration of wealth. For outside the Convention, though present "virtually," was John Adams, whose recently published book, A Defence of the Constitutions of Government of the United States, volume 1, was on sale in Philadelphia and likely included in the collection of the Library Company of Philadelphia, to which the Convention delegates had free access. ${ }^{4}$

\footnotetext{
${ }^{4}$ Adams' book was listed in the Library's catalogue of 1807, which had absorbed and replaced the catalogue of 1789 (http://librarycompany.org/about/history.htm). Luther Martin of Maryland once referenced Adams' Defence during the debates (June 27, 1:439); and Madison spoke of it in a June 6 letter to Jefferson (The Papers of James Madison, eds. Robert Rutland, et. al. [Chicago: University of Chicago Press, 1977], 10:29). The editor of the Works of John Adams, Adams' grandson, Charles Francis Adams, stated that the edition printed in Philadelphia "was much circulated in the convention" (Boston: Little, Brown \& Co., 1850-56), 4:276. That point was partly confirmed by John Adams' friend, Cotton Tufts, who informed Adams in June that his book "came to America at a very critical moment just before the meeting of the grand convention at Philadelphia for revising and amending the confederation, when the subject of your book will naturally be much talked of and attended to by many of the greatest statesmen from all parts of the United States (quoted by Page Smith, John Adams, vol. 2 [Garden City, NY: Doubleday \& Co. 1962], 698-99). Benjamin Rush was among the statesmen favorably impressed, reporting in a letter to Richard Price that "Mr. Adams's book has diffused such excellent principles among us, that there is little doubt of our adopting a vigorous and compounded federal legislature (Farrand, Federal Convention, 3: 33).
} 
Adams used the word "ostracism" to describe the exclusion of the rich, the well-born, and the able from the lower house of a legislative body. ${ }^{5}$ Segregating society's luminaries was the function of an upper house, he reasoned, for if allowed to commingle with persons of lesser talents, these "natural aristocrats," as he styled them, ${ }^{6}$ would rise to the top and quickly take command, robbing the lower house of its distinctive quality. But with the classes kept apart in separate chambers, the two chambers would be genuinely different and able to check each other.

Morris' July 2 intervention seemed then to be channeling Adams' thought. But not only Adams', for behind Adams stood the great Florentine political philosopher, Niccolò Machiavelli. Adams reproduced selections from Machiavelli's Discourses on Livy in volume 1 of his Defence; and in volume 2 he provided a 100-page transcription of and commentary on Machiavelli's Florentine Histories, plus an abridgement and critique of Machiavelli's Discourse upon the Proper Ways and Means of Reforming the Government of Florence. C. Bradley Thompson discusses the Machiavellian influence on Adams. ${ }^{7}$ Other scholars find echoes of Machiavelli in the writings of Alexander Hamilton and Thomas Jefferson. ${ }^{8}$ No one before though has suggested that Machiavelli

\footnotetext{
5 J. Adams, Work, 4:290-91, 444-45; 5:185-87.

${ }^{6}$ Ibid,. 4:397.

${ }^{7}$ C. Bradley Thompson, “John Adams’ Machiavellian Moment,” Review of Politics 57 (Summer, 1995): 389-
} 417.

${ }^{8}$ Hamilton is counted a disciple despite the presence of only two Machiavelli citations in his works, both of them negative (Karl Walling, "Was Alexander Hamilton a Machiavellian Statesman?” Review of Politics 57 [Summer, 1995]: 419-47); while Jefferson is counted a disciple on the strength of one citation, also negative (Paul A. Rahe, “Thomas Jefferson's Machiavellian Political Science,” Review of Politics 57 [Summer, 1995]: 449-81). Claiming for Jefferson an indebtedness to Machiavelli, Rahe says, "one does not have to cite an author or, for that matter, even peruse his works to absorb something of his doctrine and to come under his sway"; and, "Machiavelli exercised a 
affected the constitutional thinking of Gouverneur Morris. In making that case, ${ }^{9}$ I am mindful of the fact that Morris was an "inconstant" thinker and a "fickle" personality. One of the many

species of intellectual hegemony over republican thought in the eighteenth century exceeded by none but John Locke" (450-51). John Lamberton Harper, who develops the parallels between Hamiltonian and Machiavellian foreign policy, says, "only the frank and feisty Adams admitted to having learned from Machiavelli" (American Machiavellian: Alexander Hamilton and the Origins of U.S. Foreign Policy [Cambridge: Cambridge University Press, 2004], 5.

${ }^{9}$ Whether Morris ever read, much less absorbed and consciously utilized, Machiavelli cannot be conclusively established. His home in Westchester County, New York, called Morrisania, contained some 4,000 volumes, far exceeding (says one biographer) the family libraries of all the Founders combined. In the estimation of contemporary Ezra Stiles, the library at Morrisania was second only to that of Harvard College. Very possibly, but not for certain, works by Machiavelli were a part of the collection. The contents were never inventoried, and during the British occupation, the books were dispersed, stolen, or destroyed (William Howard Adams, Gouverneur Morris: An Independent Life [New Haven: Yale University Press, 2003], 11-12, 75-76; James J. Kirschke, Gouverneur Morris: Author, Statesman, and Man of the World [New York: Thomas Dunn Books, 2005], 10). It can though be established that for all the years that Morris lived in Philadelphia, he had ready access to Machiavelli, because a two-volume Works of Nicolas Machiavel, plus a separate edition of Machiavelli's History of Florence, were listed in the 1770 catalogue of the Library Company of Philadelphia and so included in its holdings (http://librarycompany.org/about/history.htm). Morris (to my knowledge) did not cite Machiavelli in any of his writings, public or private, but then Morris cited rather few authors, and the ones he did cite were generally poets and playwrights. Montesquieu he cited, and Roman history he referenced, including, late in life, a comparison of Roman religion and Christianity (J. Jackson Barlow, ed. To Secure the Blessings of Liberty: Selected Writings of Gouverneur Morris, [Indianapolis: Liberty Fund, 2012], 647-48), a prominent theme in the Discourses (e.g., 2.2.2). But the fact remains that the case for Machiavellian influence is circumstantial. Readers who require more should then suppose the paper to be exploring an uncanny similarity in the thinking of Morris and Machiavelli that goes to explain why Morris was not the same sort of nationalist as Madison. Readers less uncomfortable with circumstantial evidence might further suppose, with me, that Morris was actually drawing on Machiavelli, applying the Florentine's mixedregime reasoning to the constitutional problems encountered at the Convention, especially the true nature and right 
biographies of him is titled “An Incautious Man”. ${ }^{10}$ Of course, Morris' incaution, or impetuosity, might just be another point of contact with Machiavelli.

organization of the legislative and executive powers. Of course, to suggest that Machiavelli was a background, intellectual source for Morris is not to deny that foreground, experiential influences were also at work, such as Morris' time in New York politics, in the Continental Congress, and in the offices of Robert Morris.

${ }^{10}$ Melanie Randolph Miller, An Incautious Man: The Life of Gouverneur Morris (Wilmington, DE: ISI Books, 2008). Morris is the subject of this and of ten previous biographies: Jared Sparks, The Life of Gouverneur Morris, with Selections from His Correspondence and Miscellaneous Papers, 3 vols. (Boston: Gray \& Bowen, 1832); Theodore Roosevelt, Gouverneur Morris (Boston: Houghton, Mifflin \& Co., 1888); Daniel Walther, Gouverneur Morris: Witness of Two Revolutions (New York: Funk \& Wagnalls Co., 1934); Howard Swiggett, The Extraordinary Mr. Morris (Garden City, NJ: Doubleday \& Co., 1952); Max M. Mintz, Gouverneur Morris and the American Revolution (Norman, OK: University of Oklahoma Press, 1970); Mary-Jo Kline, Gouverneur Morris and the New Nation, 1775-1778 (New York: Arno Press, 1978); W.H. Adams, GM: An Independent Life, 2003; Richard Brookhiser, Gentleman Revolutionary: Gouverneur Morris, the Rake Who Wrote the Constitution (New York: Free Press, 2003); Kirschke, GM: Author, Statesman, 2005; and Melanie Randolph Miller, Envoy to the Terror: Gouverneur Morris and the French Revolution (Dulles, VA: Potomac Books, 2005). But however often and welltold his life story, the political thought of Morris has received relatively little scholarly attention: one article (Donald L. Robinson, "Gouverneur Morris and the Design of the American Presidency," Presidential Studies Quarterly 17 [1987]: 319-28); one book chapter (Jennifer Nedelsky, Private Property and the Limits of American Constitutionalism, chap. 3 [Chicago: University of Chicago Press, 1990]); several pages of another book chapter (Nathan Tarcov, "The Social Theory of the Founders," in Confronting the Constitution, ed. Alan Bloom [Washington, D.C.: AEI Press, 1990]); an unpublished doctoral dissertation (Arthur P. Kaufman, "The Constitutional Views of Gouverneur Morris," Ph.D. diss. [Georgetown University, 1992]); and an online essay (Forrest McDonald, "The Political Thought of Gouverneur Morris," [theimaginativeconservative.org., 2013]). One of the biographies listed above devotes a chapter to Morris' role in writing the Constitution (Kirschke, GM: Author, Statesman, chap. 5). 


\section{Senate}

In a country without a titled nobility to represent, such as the peers of Great Britain, what was the purpose of an upper house? That question was raised by the French economist Jacques Turgot in a letter to the English moral philosopher, dissenting minister, and political pamphleteer Richard Price. The reprinting of Turgot's letter in 1784 was what prompted Adams to write his three-volume tome defending the bicameral structure of America's newly formed state governments and their adoption of separated powers. At the Convention, George Mason of Virginia confidently pronounced that the American mind-apparently unaffected by Price and Turgot—was settled in favor of bicameralism (June 20, 1:339).

Perhaps not entirely settled, however, as Charles Pinckney of South Carolina came very close to reposing the Turgot question. ${ }^{11}$ In a lengthy speech delivered on June 25, Pinckney described America as an egalitarian country without Old World social orders or concentrations of great wealth; with only occupational classes of little consequence, because these classes were politically equal and mutually dependent, so much so that they effectively had but one interest. Moreover, with a vast and empty frontier to inhabit, the country was destined to remain "but one great \& equal body of citizens" for many years to come (1:397-404). Hence no reason existed to imitate the British constitution, however well-suited for Britain it might be. ${ }^{12}$

\footnotetext{
${ }^{11}$ Unicameralism was in fact the preference of a number of delegates. Those who spoke for it were Benjamin Franklin (May 31, 1:48), William Paterson (June 16, 1:251), Oliver Ellsworth (June 16, 1:255), John Lansing (June 20, 1:336), Luther Martin (June 20, 1:340; June 27, 1:439), and Roger Sherman (June 20, 1:341, 343).

${ }^{12}$ Pinckney did favor a senate, but he gave no reason why; nor did he in the June 25 speech say much about its organization. His plan of government, placed before the Convention on May 29, supplied a few details. The Pinckney Plan is a complicated affair: see Farrand, Federal Convention, 2:134-37; 3:106-23, 427-28, 595-609.
} 
Morris missed Pinckney's speech, but his own speech on July 2, coupled with those on July 6 and July 19, seemed designed as a rebuttal. The object of the second branch, Morris maintained, was "to check the precipitation, changeableness, and excesses of the first branch." The misbehavior of state legislatures — which had inspired Virginia's James Madison to pen his pre-Convention memorandum, "Vices of the Political System of the United States," and which served as the premise for many of his Convention proposals-was cited as evidence that lawmaking by the people's representatives posed a clear and continuing danger to "personal liberty private property \& personal safety" (1:512). Society was not one equal and interdependent mass, as supposed by Pinckney, but consisted of individuals of differing stations, any few of whom could be oppressed by the remainder.

The checking function of the second branch, Morris claimed, depended on three essential elements: interest, property, and independence. While not dismissive of "Abilities and virtue," Morris put greater store by personal interest: “... one interest must be opposed to another interest. Vices as they exist, must be turned against each other." Vice checking vice was the secret, not wisdom enlightening ignorance or goodness overcoming wickedness. For Morris, personal property, accompanied by an "aristocratic spirit" that "love[d] to lord it thro' pride," was the interest and the attitude that properly defined a senate. He allowed that pride was present across the human species but that it showed differently in the poor than in the rich. In the poor it was reactive and resisting, in the rich assertive and abusive. But notwithstanding the more aggressive nature of the rich, the poor generally predominated because of their huge advantage in numbers. Politically this meant that upper houses were creatures of lower houses, and experience at the state level seemed to confirm the relationship. On the other hand, if provided a mode of election independent of the people and of their representatives, specifically appointment by the executive, along with lifetime tenure, senators would have the means and the motive to defend the 
prerogatives of their office. But would not rich and prideful senators, serving for life, do wrong, Morris asked. His answer was likely intended to stun: "He believed so; he hoped so." (1:512). He hoped so!

Madison, who would go as high as nine years for a senatorial term, hoped for "wisdom \& virtue" from the senators, not wrongdoing, because he envisioned them as "the impartial umpires and Guardians of justice and general Good" (June 26, 1:423, 428). After the Convention and writing as Publius, Madison paraphrased Morris' "vice checking vice" line, stating in Federalist 51, "ambition must be made to counteract ambition." 13 The purpose though of counteracting ambition was to control humanity's non-angelic nature, not to afford it fresh opportunities for misconduct and to showcase its harm. ${ }^{14}$ Likewise, Adams was not naïve in outlining the characteristics of natural aristocrats. Their special talents, he recognized, could easily be put to selfish purposes and result in "the destruction of the commonwealth". ${ }^{15}$ But promotion from the lower to the upper house, he supposed, would work as an inducement to good behavior: "The senate becomes the great object of ambition; and the richest and the most sagacious wish to merit an advancement to it by services to the public in the house". ${ }^{16}$ Among the champions of checks and balances, Morris then was exceptional in hoping for wrongdoing, and even Alexander Hamilton of New York, who with Morris supported lifetime terms, did so in order to "high-tone" the senate (June 26, 1:424).

${ }^{13}$ Alexander Hamilton, John Jay, and James Madison, The Federalist (Indianapolis: Liberty Fund, 2001).

${ }^{14}$ Lance Banning minimizes the importance of ambition-checking-ambition in Madison's thought (The Sacred Fire Of Liberty: James Madison and the Founding of the Federal Republic [Ithaca, NY: Cornell University Press, 1995], 368).

15 J. Adams, Works, 4:397.

${ }^{16}$ Ibid., 4:291. 
Very similar to Morris, and possibly the source for his ruminations on the senate, is Machiavelli. In Prince 9 Machiavelli states that two social classes, which he calls humors, are present in every city. There is the humor of the great-Morris' aristocrats, likewise said to exist in all civilized societies (July 6, 1:545) — and the humor of the people. The great, or grandi, want to dominate and oppress; the people, or popolo, want to escape the domination and oppression of the great. Machiavelli seems to be taking sides. The same could be said of Morris, whose denunciation of wealth was uncompromising: "Wealth tends to corrupt the mind \& nourish its love of power, and to stimulate it to oppression. History proves this to be the spirit of the opulent" (July 19, 2:52).

The division between the humors reappears in the Discourses on Livy: “. . . in every republic are two diverse humors, that of the people and that of the great, and . . all the laws that are made in favor of freedom arise from their disunion" (D.1.4.1). ${ }^{17}$ Freedom arises from the mutual suspicion and animosity of distinct social classes armed with the means of self-defense. Most previous commentators, including Livy, Machiavelli's source, condemned Rome's tumultuous domestic life, ${ }^{18}$ Machiavelli, on the contrary, credits tumults with providing Rome its good laws and good education, which in turn occasioned countless acts of personal virtue.

The story of how the Roman humors acquired their institutional arms is told by Machiavelli in Discourses 1.2-3. With the expulsion of King Tarquinius Superbus, the patricians assumed

17 Citations of Machiavelli's Discourses on Livy are from Harvey C. Mansfield and Nathan Tarcov, trans. (Chicago: University of Chicago Press, 1996); those of The Prince are from Harvey C. Mansfield, trans., $2^{\text {nd }}$ ed. (Chicago: University of Chicago Press, 1998); and those of the Florentine Histories are from Laura F. Banfield and Harvey C. Mansfield, Jr., trans. (Princeton: Princeton University Press, 1988).

18 Titus Livy, Ab Urbe Conditia, trans. B.O. Foster, vol. 2 (Cambridge, MA: Harvard University Press, 1922), 4:9. 
command of the city and Rome became in effect an aristocracy, or a partial mixed regime with consuls taking the place of kings (D.1.2.7). But far from domineering and oppressing, the patricians "behaved humanely" toward the people. Machiavelli accounts for this apparent contravention of his verdict on the great and of his wider judgment that "all men are bad," or must be presumed bad by those who order republics, ${ }^{19}$ by claiming that "when any malignity remains hidden for a time, this proceeds from a hidden cause" (D.1.3.1). Good government in early republican Rome resulted then from a hidden cause, specifically the patricians' fear that the people would restore the Tarquins if mistreated by their new rulers. Thus, for as long as any of the royal line was alive and residing nearby, the nobles refrained from revealing their true, malignant nature. This circumstance obtained for thirteen years, from 509 to 496 B.C., not quite enough time, in Machiavelli's estimation, for the plebs to have surrendered their pride and slumped into a state of credulous docility. The death of the last of the Tarquins was the "accident" that released the nobles from their fear and awakened the plebs to their danger. When the nobles turned abusive, the people mustered their reactive pride and resisted, abandoning the city until the office of the tribunate was conceded to them as an instrument of self-protection. Rome then passed from a partial mixed regime to a "perfected" mixed regime, combining kingly (consuls), aristocratic (senate), and democratic (tribunes) elements. A popular assembly was added some years later. ${ }^{20}$

\footnotetext{
${ }^{19}$ Morris uttered similar sentiments in a letter to Washington dated October 30, 1787: “. . . men must be treated as men, and not as machines, much less as philosophers, and least of all things as reasonable creatures, seeing that in effect they reason not to direct, but to excuse, their conduct" (Sparks, Life of GM, 1:290).

${ }^{20}$ This was the plebian council, or concilium plebis, the origins of which are obscure. Its decisions, called plebiscites, applied only to the plebs, until 287 B.C., when, with passage of the Hortenisan law, the plebeian council was folded into the tribal assembly, or comitia tributa. See Kurt von Fritz, The Theory of the Mixed Constitution in
} 
Why would Morris hope for wrongdoing by the rich quarantined in an upper house of their own? Because a well-defined class opponent, whose malignity was on full display, would arouse the jealousy and distrust of the people; and because an aroused and vigilant people would safeguard their liberty against encroachments by the wealthy. "By thus combining \& setting apart, the aristocratic interest," Morris thought, "the popular interest will be combined against it. There will be a mutual check and mutual security" (July 2, 1:513). ${ }^{21}$ Jennifer Nedelsky puts it thus: "It was as though the isolation of the rich in an explicitly aristocratic body would alert the people to their threats; it would be harder for the wealthy to pass off their interests as the public interest."22 Arthur Kaufman emphasizes these institutional markers: "As representatives of a national class, [senators] could more readily be held to account for their positions on national legislation: 'The aristocracy (the wealthy) support, or the aristocracy (the wealthy) oppose, this legislation,' it might be said."23 On the other hand, if the two classes were intermixed in an upper house constituted along the lines of the lower house and elected popularly, either an oligarchy or a democracy would develop, depending on whether the society was commercial or agrarian.

Antiquity (New York: Columbia University Press, 1954), 236-38; Claude Nicolet, The World of the Citizen in Republican Rome (Berkeley: University of California Press, 1980), 224-25, 228.

${ }^{21}$ Morris applied his analysis of class division and the legislative power to French politics, when two years later he was in Paris witnessing the demise of the Estates General: "Suppose all distinctions gone, and one body of representatives appointed for this great kingdom, on whom will the choice fall? .... Will not the rich and the great be chosen? ... Is it not most wise to put all these enemies in one body together, and not suffer them to elude the vigilance of observation, by dressing in the popular garb? Why suffer the wolves, (if wolves they be) to occupy the place, which should be reserved for the shepherd?" (Barlow, Selected Writings of GM, 235).

${ }^{22}$ Nedlesky, Private Property, 80.

${ }^{23}$ Kaufman, “Constitutional Views of GM,” 335. 
The former result received considerable attention from Morris. Commerce would remove the poor from farms to cities, where they would be put to work as manufacturers and mechanics in the employ of factory owners and at their mercy. If also enfranchised, the voting poor would feel the influence of their economic masters, if not have their votes outright bought, and the power of the aristocracy would increase thereby (August 7, 2:202-03). ${ }^{24}$ Further advantage would accrue to the rich if the country were also large, as they would have the resources to "communicate \& act in concert" across great distances. The rich would manipulate the passions of the people and "make these the instruments for oppressing them"; while the people, "never act[ing] from reason alone," would "be the dupes of those who [had] more knowledge \& intercourse." Madison argued that size and diversity would break apart economic factions, forcing the construction of temporary coalitions for electoral and legislative purposes; and that moderation and justice would be the inadvertent byproducts of this necessity to combine and recombine for political success (June 6 , 1:134-36). Morris concluded, contrarily, that a "violent aristocracy" would be the result of an extended, commercial republic lacking a class-identified bicameral legislature (July 2, 1:514). ${ }^{25}$

Morris did not explain why in an agrarian society a democracy would emerge from the legislative intermixing of rich and poor, except to reference the historical record as certain proof. Perhaps he supposed that with agriculture would come small, uniform, egalitarian republics, whose politics would perforce be a reflection of the popular interest. ${ }^{26}$ Perhaps he meant to apply that

\footnotetext{
${ }^{24}$ In a letter to Robert R. Livingston dated October 10, 1802, Morris described universal suffrage as an aristocratic feature of American government, notwithstanding its democratic form (Sparks, Life of GM, 3:172).

${ }^{25}$ Robinson, "GM and the American Presidency," 324.

26 Commercial society produces complexity, disparities of wealth, and community-wide avariciousness incompatible with democracy, which requires simplicity, equality, and frugality (D.1.55; Nedelsky, Private Property, 88).
} 
other side of his analysis whereby upper houses were the "creatures" of lower houses, sinking into "servile complaisance" if deprived of those institutional protections that made for their independence: e.g., non-popular election, life tenure, property qualifications. An upper house that merely replicated the lower house was worse than useless, and a government would be "better without it," thought Morris (July 2, 1:512).

Machiavelli is also alarmed by the prospect of patricians becoming like plebeians, as might happen if the former courted the votes of the latter. ${ }^{27}$ Rome was once saved by its senators when they resisted the people's demand for relocating half of the population to Veii, an Etruscan town conquered by Rome but more splendid in its buildings and countryside. Because the senators represented a distinct social order, they had the wherewithal, and some of them the personal authority, to face down the inflamed populace. Persuading the public is difficult, says Machiavelli, because a policy that promises gain and excites the spirit will always be preferred by the people, notwithstanding the loss and danger contained within. As a case in point, Fabius Maximus was unable to persuade his fellow citizens of the wisdom of delaying combat with Hannibal, because delay seemed cowardly and because quick success was assured by others; consequently, three illconceived battles were fought and lost, causing the near ruin of Rome (D.1.53.1-2).

This turnabout in portrayal from malignant oppressors to wise and careful counselors occurred in Morris too. It is to be remembered that Morris introduced the senate as a careful, sober check on the unwise haste and inconstancy of the lower house. In that vein (though not yet

\footnotetext{
${ }^{27}$ In the Florentine Histories, Machiavelli praises the Roman nobility for extending governing opportunities to the plebs in a manner that encouraged them to imitate the martial qualities of the nobles; and he blames the Florentine populace for withholding governing opportunities from the nobles unless they conducted themselves in a manner similar to the people (3.1).
} 
reported), he proceeded to describe senators as among "the best, the most able, and the most virtuous citizens"; he defended their lifetime appointment as a safeguard against a change of measures; ${ }^{28}$ and he charged them with responsibility for service as a "select and sagacious body of men, instituted to watch against [encroachments] on all sides." Rather than one of the sides from which encroachments were anticipated, the senate was now depicted as rising above the competition and operating as a guard. Nedelsky accounts for the change by postulating "ambivalence" in Morris toward the rich; ${ }^{29}$ Nathan Tarcov calls it "an extra fillip on top of the more solid considerations of class interest, human pride, and institutional responsibility." 30 More likely though—or additionally—it was a recognition that with a different set of interests, different behaviors could be expected. Because senators would have lifetime appointments, the long-term well-being of the country and the effectiveness of government would become their concern. Dedication to the common good would arise from the alignment of class interest with the public interest. This potential for good was best captured in the notes of Robert Yates, who recorded Morris as saying: "Give them the second branch and you secure their weight for the public good. They become responsible for their conduct ...” (July 2, 1:517; also July 6, 1:545). ${ }^{31}$ Morris, it seems, did not discount the possibility that effective checking of senatorial malignity, coupled with exposure and responsibility, might result in enlightened behavior beneficial to all. Perhaps in the end Morris was attempting to co-opt a portion of the rich, installed as permanent lawmakers, to

\footnotetext{
${ }^{28}$ Barlow, Selected Writings of GM, 237.

${ }^{29}$ Nedelsky, Private Property, 80-81.

${ }^{30}$ Tarcov, "Social Theory of the Founders," 177.

${ }^{31}$ Morris attributed such far-seeing stewardship to the British king, whose tenure was hereditary (July 20, 2:68;
} July 21, 2:76). 
police the remainder of the rich, busy with money-making in the private economy-i.e., a quasiaristocracy recruited from the oligarchical class. ${ }^{32}$ Extracting good from bad, and not just preventing bad, was a small, but real, part of Morris' constitutional thinking.

In the main though Morris put his faith in vice rather than virtue. On three other occasions during the July 2 speech did Morris show himself accepting of the dark side of human nature. Appointment of senators to executive offices - tightly circumscribed under the Virginia Plan (Resolution 5)—was approved by Morris for the somewhat scandalous reason that competent government rested on influence, which Hamilton, when taking the same position on June 22, was happy to call corruption (1:376). Morris opposed payment of senators, but not for the high-minded reason given by Benjamin Franklin when discussing the presidency—that non-payment would attract the "wise and the moderate" rather than the "bold and the violent" and that the example of General Washington, who had accepted no pay during the eight years of war, proved the feasibility of gratis service (June 2, 1:82, 84-85). No, because senators would find sub-rosa ways of paying themselves and because non-payment would accomplish a property qualification without having to legislate one. And whereas Adams saw election to the upper house as an encouragement to and reward for good behavior, Morris saw it as a "bribe" and "noble bait" for demagogues in the states (July 2, 1:513-14).

In sum, when Morris took the floor on July 2, reintroducing himself to the Convention, he provided the delegates with a blueprint for the national legislature, modeled on, or reminiscent of, a Machiavellian mixed regime, in which a plebeian house was checked by a patrician senate, each the class enemy of the other. But unless the senate was distinctive in character and design, its

32 Machiavelli includes co-optation among the techniques of indirect rule practiced by the Roman senate (D.3.11.1). 
independence ensured by a mode of election free of popular influence, it would, Morris argued, succumb to the house, standing for the people; or, in a large commercial society, an oligarchy would emerge as the rich, being better organized and informed, would manipulate and buy off the poor. Accordingly, Morris required his senators to be wealthy, prideful grandees with lifetime, unpaid appointments made by the executive, and confined to a chamber of their own. As a side benefit, the Convention's month-long squabble over equal vs. proportional representation became a moot point. The senate would not be representing states or people, but property, with members selected irrespective of residence. Resetting a stalled debate may have been for Morris a second intention, along with apprising the Convention of an older science of politics, originating with Machiavelli and promoted by Adams.

\section{Presidency}

As he had done with the senate on July 2, so on July 19 Morris offered a comprehensive statement regarding the purpose and organization of the executive. And as he had astounded the delegates with his proposal for a lifetime senate representing wealth, so again he astounded them with his description of the president as the "guardian of the people" (2:52). Most delegates gave that distinction to the legislature, especially its lower house. For example, Elbridge Gerry of Massachusetts claimed that he "relied ... on the Representatives of the people as the guardians of their Rights \& interests" (July 21, 2:75).

The origin of this expression, "guardian of the people," and later "guardian of liberty," may trace to Machiavelli, who devotes two chapters of the Discourses to the constitutional function of guarding. In Discourses 1.5 Machiavelli asks which of society's humors, the great or the people, provides a more reliable guard of freedom. Guardianship appears not to be a separate office of state, but a disposition to defend the constitution, its distribution and balance of power. As Machiavelli frames the issue, the candidates for the title are themselves combatants in the struggle 
for class ascendancy; so a guardian is one who simultaneously is an interested party and a judge who holds all parties in their place. Machiavelli admits that the question is not easily settled, because history and reason suggest opposing answers. Among ancient republics, Sparta trusted its nobles with the task of guarding the constitution, as did Venice among modern republics; and both preserved their liberty longer than did Rome, which trusted the guardianship to the people. But a different answer is arrived at through reason, which inquires into the motivations and behaviors of actors and discovers that those who possess wealth and power never cease from their acquisitive labors, because they are anxious and fear losing what they hold already unless more of the same is added; also, they have resources and are better positioned to acquire. (Morris' rational inquiries arrived at the same conclusion, that the wealthy were insatiably rapacious, and that they also possessed the means to "communicate \& act in concert.") The argument is consonant with Machiavelli's other judgment that the great wish to oppress and the people wish not to be oppressed. As for the contrary evidence of history, Machiavelli disposes of it by distinguishing between expansionary and non-expansionary states. The former, of which Rome was the prime example, need the populace to fight their wars and so must bend toward the popular interest; while the latter, with Sparta and Venice as examples, can afford to depoliticize the people. Tumults are the result of a politicized people, who have the military training and institutional representation to act on their envy and resentment. The other part of the chapter's title, besides guarding freedom, is causing tumults, and Machiavelli blames the "incorrect and ambitious behavior" of the great for rousing avarice in the people and tumult in Rome (D.1.5.4).

Machiavelli continues the discussion in the following chapter, but with a focus on the constitutions of Sparta and Venice, whose mixed regimes, without a popular component, were aristocratic republics, Rome's, by contrast, a democratic republic. What prevented the oppression of the people by the great in these two aristocratic republics? In the case of Sparta, its two kings 
defended the people as a way of defending themselves against the nobles, with the result that the people, not fearing oppression, did not desire a share of rule; and the state, restricted in size and wealth by the laws of Lycurgus, could be governed by a few who socially were not so different from the many (D.1.6.2). In the case of Venice, the status of noble was extended to all early inhabitants, who were called gentlemen, while later arrivals became the populace without political rights. The ruling class was too numerous to profit from oppression, and the ruled had neither cause nor opportunity to revolt, because nothing was taken from them or asked of them, and their numbers were always kept fewer than that of the gentlemen class (D.1.6.1). Accordingly, the aristocratic republics of Sparta and Venice were for many centuries united, tranquil, and free, but at the cost of staying small; while the democratic republic of Rome, for some shorter period of time, was united, tumultuous, and free, but with the prospect of growing great. Machiavelli prefers expansionary Rome, because, as he famously pronounces, necessity mandates expansion, and a state not ordered for it will one day be destroyed by external or internal forces (D.1.6.4).

Morris might initially have conceived of the senate as the guardian of liberty, for he described it, as observed, as a "watch against [encroachments]"; but then the Convention did not give him the senate he wanted — an aristocratic body with members serving for life. He certainly did not follow Machiavelli in placing the guard of freedom with the people, or with a tribunate or assembly providing them protection (D.1.6.4). On the other hand, the part played by Machiavelli's Spartan kings was strikingly similar to that which Morris assigned to the president; ${ }^{33}$ and possibly Morris intended the president for the role all along. The advantage of such an arrangement would

\footnotetext{
${ }^{33}$ The guard of freedom shifts in Machiavelli from the Spartan nobles to the Spartan kings. Likewise in Morris,
} the guard shifted from the aristocrats (maybe) to the president. 
be a guardian from outside the social orders operating as a neutral umpire, rather than a guardian from within trying not to operate as a judge in its own case.

Morris placed the president at the center of a system of governmental checks and balances, responsible for blocking the senate, the house, and the legislature entire, all the while guarding the people, including "the lower classes." Legislative tyranny was Morris' primary worry, partly because he foresaw the absorption of the lower house by the upper, as "the Great $\&$ the wealthy" would "in the course of things ... necessarily compose the Legislative body." Failure to segregate property in a separate chamber, combined with the oligarchical effects of commerce, might have been the reasons for this dire prediction. A united, and effectively unicameral, legislature-its lower house "seduced" by its upper - posed a mortal danger to the independence of the executive, whose work as "protector of the Mass of the people" required that it first defend itself (July 19, 2:52) - the same co-dependent relationship that existed for the Spartan kings. All of Morris' executive-branch proposals aimed at establishing the executive's independence, ${ }^{34}$ under threat by the humor of the great and acting for the benefit of the humor of the people. In short, the president was to be what Machiavelli calls a "civil prince," an executive who suppresses the great and befriends the people.

The title of Prince 9 is "Of the Civil Principality." Machiavelli is in midst of delineating different kinds of princes (virtuous, fortunate, criminal), and the civil prince is said to be one who comes to power "with the support of his fellow citizens." That support is not registered by election, however, for the city Machiavelli presents is on the cusp of civil war, and the factions are each searching for a champion to help them defeat their class opponent. This is where the humors are introduced, and the result of their competition, Machiavelli reckons, is "principality or liberty or

\footnotetext{
${ }^{34}$ Kaufman, “Constitutional Views of GM,” 338, 351, 357.
} 
license." The last of these outcomes, license, most likely describes the triumph of the people in a simple, democratic regime; for "the popular is without difficulty converted into the licentious," says Machiavelli in the Discourses (1.2.2). Principality, the first of these outcomes, most likely describes the transition of a civil prince (the chapter's title) into an absolute prince (the chapter's end). Having come to power at the head of the popular cause, the prince might later choose to cast off all restraints and oppress the people no less than the great. This princely absolutism appeared also in Morris' July 2 speech, which warned of "a violent aristocracy, or a more violent despotism" resulting from the contest of the humors (1:514). In other words, when the few and the many, in a commercial society, fall into class strife, the fate of the many, barring the construction of a civil principality, is either oppression by the few ("violent aristocracy") or oppression by one ("violent despotism"). ${ }^{35}$ Liberty, the second outcome, would seem to describe the relationship of the civil prince to the people, whose standard-bearer he has become. If the civil prince, content to rule through magistrates and guard the people, resists the temptation to seize absolute power-and Machiavelli specifies the hazards involved without supplying a remedy, as if to discourage the attempt — then liberty obtains. ${ }^{36}$ Machiavelli has no institutional contrivance to curb the ambition of princes, at least not in The Prince, only the advice of a wise counselor. Morris, on the other hand, did —namely election, impeachment, and term of office.

35 Kaufman is of a different mind, describing violent despotism as majority tyranny (ibid., 333). Nedelsky attributes the rise of both violent aristocracy and violent despotism to the misguided participation of the public (Private Property, 87). Perhaps though it would be better to say that majority tyranny and misguided populism correspond to Machiavelli’s licentious democracy coming to power in Morris' agrarian society.

${ }^{36}$ The liberty outcome associated with civil principality is not to be confused with the political liberty of a republic, presented in Discourses 1.4.1. For the classes in Prince 9 are, after all, vying with each other to surrender their political liberty to a prince in exchange for protection and vengeance. 
The prince in Prince 9 is cautioned against assuming power with the aid of the great, whose jealousy can never be assuaged and who are conniving and quick to act; by contrast, the people are "more decent," more easily satisfied, and too numerous to have as an enemy. Also, the people, but not the great, are grateful, especially so, when expecting harm, they receive benefits instead. The suggestion is that a prince should first befriend the great, making use of their astuteness and energy; switch sides at the first opportunity, thereby ridding himself of envious and conspiracyprone supporters; and end by extending protection to the people.

Discourses 1.16.5 recreates the situation in Prince 9: domestic strife; an exiled former tyrant brought back to lead the aristocratic faction; a reversal of course, with the repatriated tyrant, now technically a civil prince, betraying his allies and offering them up to the vengeance of the people; and a partial restoration of freedom. Security under the rule of law is the part of freedom that is restored to the people, not a share of power, which Machiavelli judges to be unnecessary because only "a small part of them desires to be free so as to command, but all the others, who are infinite, desire freedom so as to live secure." Machiavelli calculates that the political class, or those with whom power is shared, amount to no more than "forty or fifty citizens" in any republic; for the remainder, security is freedom enough.

Morris' executive, here compared to a Machiavellian civil prince, was, as noted, a guardian of the people in place of the people themselves. Morris feared that the people, on account of economic dislocations, would, in a short time, be too corrupt to serve in that capacity: "Will [mechanics and manufacturers] be the secure \& faithful Guardians of liberty? Will they be the impregnable barrier against aristocracy?" (August 7, 2:202). Assuming negative answers to these questions, Morris transferred guardianship to the president, a "great and illustrious" character who likely would hail from the nation's wealthy elite (July 17, 2:31). But he would not endeavor to advance their interests or satisfy their ambitions, since they, like Machiavelli's great, would 
"always covet his seat ... perplex his administration ...cabal with the Legislature, till [they succeeded] in supplanting him" (July 24, 2:104; also August 24, 2:404). He rather would protect the people from the predatory behavior of his own kind, providing security under law, the sort of freedom the people actually desired. ${ }^{37}$

But while a guardian of the people, the president would not quite be an advocate for the popular interest, passing "bad laws" on the people's behalf. ${ }^{38}$ The people were noted for favoring paper money, tender laws, cancellation of debts, and redistribution of land (July 19, 2:52; July 21, $2: 76) .{ }^{39}$ The president would oppose these populist measures for the sake of property rights, the sanctity of contracts, and a sound economy, without which civilized society could not exist. ${ }^{40}$ In

\footnotetext{
${ }^{37}$ Morris may not have wanted the people taking a too-active role in politics. In short essays dating to the Revolutionary period, titled (sometimes) Political Enquiries, Morris made clear his preference for civil liberty-the individual's right to be left alone — over political liberty — the collective's right to rule. In fact, Morris spoke quite disparagingly of political liberty: "A Nation of Politicians, neglecting their own Business for that of the State, would be the most weak miserable and contemptible Nation on Earth" (Barlow, Selected Writings of GM, 7). Morris certainly did not neglect his own business: on four separate occasions, when important affairs of state were pending, Morris excused himself for a time, or altogether, often to attend to his private concerns (Kirschke, GM: Author, Statesman, 54-55, 69, 167, 200; also, W.H. Adams, GM: An Independent Life, 123-24). McDonald associates civil liberty with commerce, and political liberty with legislative action; and he connects them both to Morris' suspicion of the legislature and his promotion of the executive ("Political Thought of GM," 3). An excellent analysis of the Political Enquiries is provided by Kaufman ("Constitutional Views of GM," 39-79).

38 Judith A. Best, "Legislative Tyranny and the Liberation of the Executive: A View from the Founding," Presidential Studies Quarterly 17 (Fall 1987):705.

${ }^{39}$ For another example of bad law, see "An American," Letters on Public Finance for the Pennsylvania Packet, March 4, 1780 (Barlow, Selected Writings of GM, 124-30).

${ }^{40}$ Nedelsky, Private Property, 90-93.
} 
similar fashion, Machiavelli advises his prince to be parsimonious, rather than liberal, because in order "to maintain the name for liberality among men, it is necessary not to leave out any kind of lavish display," the sure result of which is state insolvency or imposition of confiscatory taxes (Prince 16). Responsible for holding both classes in their place, but especially the great, the president would guard the constitution that guarded the liberty of all. First, he would guard his own powers against usurpation by the legislative branch.

The people though would perform this one function - they would serve as the electorate of the executive: "If he is to be the Guardian of the people," said Morris, "let him be appointed by the people" (July 19, 2:53). On July 17 Morris first proposed popular election of the president, giving his Pennsylvania colleague, James Wilson, desperately needed support (June 1, 1:68). Aside from Wilson, Morris seemed to be the only delegate (until then) who thought the people up to the task: "If the people should elect, they will never fail to prefer some man of distinguished character, or services; some man . . of continental reputation" (2:29). ${ }^{41}$ Mason of Virginia, speaking soon after Morris, equated popular election with "a trial of colours" judged by "a blind man" (2:31). A standard argument for election by the national legislature, as per the Virginia Plan (Resolution 7), was the expected return of candidates of a higher caliber (July 17, 2:29, 30); as the standard knock on the people was their propensity to prefer unfit mediocrities for office, with deficient information, local prejudice, and a chronic susceptibility to demagogues cited as causes. Morris paired at-large, popular election with a two-year tenure, indefinite reeligibility, and immunity from impeachment (July 19, 2:53-54). The reason for this last provision was a conception of the president as a monarch in a mixed regime assisted by ministers who would stand

\footnotetext{
${ }^{41}$ Machiavelli is conspicuous in promoting the idea that the people are a competent judge of character (D.1.47;
} 1.58.3). 
trial in his stead. In furtherance of that conception, Morris alternately proposed lifetime appointment for the president should election by the legislature be approved over election by the people (2:53-54). ${ }^{42}$ Two days earlier, on July 17, the Convention committed a colossal blunder; it voted for executive election by the national legislature along with executive reeligibility, a combination of elements that vitiated executive independence. Following the vote, James McClurg of Virginia moved adoption of tenure during good behavior. Morris chimed in excitedly: "This was the way to get a good Government" (2:33). ${ }^{43}$

But Morris was not exactly recommending a monarch-like executive: He "was as little a friend to monarchy as any gentleman" (July 17, 2:35). He rather worried that a badly constructed executive (respecting mode of election, term of office, reeligibility, and removal) would provoke the people into demanding a monarch. In one particular, he rethought what a well-constructed executive required, reversing his position on impeachment. He came to realize, his "opinion [having] been changed by the arguments used in the discussion," that "our executive was not like a Magistrate having a life interest, much less having an hereditary interest in office. . . This Magistrate is not the King but the prime-Minister. The people are the King" (July 20, 2:68-69). Morris had been building his executive on the model of his senate, where the occupant[s] had "a

\footnotetext{
${ }^{42}$ Morris' flirtation with a monarch-like president had a counterpart in Machiavelli, many of whose republican leaders are described as monarch-like rulers (e.g., founders, reformers, captains). Further confusing matters, or conflating regime types, Machiavelli uses the phrase "prince of a republic" (D.1.18.4). See Morris' comments on the French constitution of 1791 (Barlow, Selected Writings of GM, 270).

${ }^{43}$ Woody Holton speculates that Morris supported popular election and a two-year, renewable term of office because, in an extensive country, a successful president would be reelected indefinitely, making the term in effect a lifetime appointment (Unruly Americans and the Origins of the Constitution [New York: Hill and Wang, 2007], 20304).
} 
personal interest in checking the other branch" (July 2, 1:512). ${ }^{44}$ Toward that end, he nudged the executive in the direction of a monarch whose person was inviolable. But conceding now that even a hereditary monarch, with the equivalent of "a fee simple in the whole Kingdom," was not immune to bribery and corruption (and he gave an example from the reign of King Charles II), Morris concluded that the president should be held liable to impeachment, provided that no dependence on the legislature resulted thereby (July 20, 2:68-69). Completing the conversion to a fully republican executive, Morris reiterated his call for a short term of office, after the Convention had heard proposals for terms as high as twenty years. He cautioned that "a long period would prevent an adoption of the plan"; and he declared, brandishing his republican bona fides, that "it ought to do so," for "he should himself be afraid to trust it" (July 24, 2:105).

Though republican, the president was to be energetic like a king. Morris began his account of the executive branch by citing "a maxim of Political Science that Republican Government is not adapted to a large extent of Country, because the energy of the Executive Magistracy can not reach the extreme parts of it" (July 19, 2:52). John Dickinson of Delaware explained why that was so in remarks on June 2, saying, "a firm Executive could only exist in a limited monarchy" because of attachments to the crown and prerogatives enjoyed by it, which no elected president could hope to match. Dickinson's remedy was "the division of the Country into distinct States" (1:86); for the states would operate — as he clarified more completely in post-Convention essays — as feudal

\footnotetext{
${ }^{44}$ Madison's statement in Federalist 51, that "the interests of the man must be connected with the constitutional rights of the place," looks again like a borrowing from Morris. Hereditary succession is the logical conclusion of this idea.
} 
magnates extending the power of the central government to the nation's outermost parts. ${ }^{45}$ Dickinson looked beyond the executive for a fix, whereas Morris challenged the rectitude of the maxim that a republican executive must be weak. For if made guardian of the people in an office structured for the purpose, the president could, Morris believed, meld together erstwhile incompatible elements, namely republican government and extensive union. ${ }^{46}$

Confronted with the same problem of republican weakness, Machiavelli commends the Romans for invigorating executive power through the office of the dictatorship. Previous writers judged the dictatorship hazardous and the cause of Rome's demise. Machiavelli takes the contrary view: republics, he observes, move in "slow motion" because power is divided and action must wait on the assent of many wills (D.1.34.3). The remedy for that disability is the capacity to unite power on the sudden, in one person alone.

Executive power in republican Rome was ordinarily divided between two consuls elected to one-year terms. The dictator was a single, uno solo, executive supplanting the two consuls and resorted to in times of emergency; the term was for six months. Despite the extraordinary character of the dictatorial power, Machiavelli calls it ordinary and safe, always doing good for the city, because it had the sanction of law and caused no scandal (D.1.34.1,3). The remaining features of the dictatorship were full authority to act, but within a limited jurisdiction, and with the existing offices of government still in operation. Full authority meant the power to decide without consultation and to punish without appeal. Limited jurisdiction meant confinement to a stipulated

\footnotetext{
${ }^{45}$ See Dickinson's Letters of Fabius, especially Letter 8 (in Colleen Sheehan and Gary L. McDowell, eds., Friends of the Constitution: Writings of the "Other" Federalists, 1787-1788 [Indianapolis: Liberty Fund, 1998], 91-97).

${ }^{46}$ Kaufmann, "Constitutional Views of GM," 392.
} 
task. And continued operation meant checks and balances, ensuring that the dictator did not “escape his limits and ... hurt the city" (D.1.34.2).

Which of these positions did Morris share with Machiavelli? Morris missed the debate on number — whether a single or plural executive - but was present when that debate resurfaced in the form of an executive council, whose consent might be required in order for the president to take action (September 7, 2:537; also June 4, 1:97). Morris opposed the measure on the narrow grounds that such a council could be used as cover for a president's bad decisions (2:542). But Morris also laid before the Convention his own plan for an executive council. Significantly, every officer of the council was to be appointed by the president and serve at his pleasure (August 20, 2:342-44), thus keeping intact executive autonomy and responsibility.

Like Machiavelli, Morris, as noted, supported a relatively short term of office, as well as popular election of the executive, which was how Rome's ordinary executives, the consuls, were chosen, though with qualifications. ${ }^{47}$ The extraordinary nature of the dictator's office had no parallel in Morris, but the reason for hiding its extraordinariness behind a veil of legal normality

\footnotetext{
${ }^{47}$ The centuriate assembly, or comitia centuriata, was where consuls and other high magistrates were elected. The senate nominated candidates. All citizens voted, but collected in "centuries" that skewed results toward the wealthy (see von Fritz, Mixed Constitution, 196, 235-36; Nicolet, World of the Citizen. 219-24). American equivalents would be the electoral college (in lieu of direct popular election), its electors chosen by state legislatures (or the mode of choosing determined by the same), and the national legislature as the elector of last resort; also, election of representatives in extended electoral districts, including at-large, state-wide elections - these matters of detail determined by state legislatures but under supervision of the national legislature. Morris generally supported such tempering devices, if only as compromises. By contrast, the election of a dictator was by the consuls themselves, because recourse to a dictator necessarily implied some deficiency in the performance of the consuls, whose loss of authority would seem less shameful if given by them freely rather than taken from them by others (D.1.34.4).
} 
did appear. The occasion was the debate over executive reeligibility. Most nationalists cited experience as their reason for preferring it, claiming that a term-limited executive would be removed from office just as he was becoming fully competent. The argument though was unconvincing and effectively met by the expedient of a single term of extended duration. Accordingly, the Convention returned again and again to the Virginia Plan's proposal for a single, seven-year term without the option of reelection. ${ }^{48}$ Morris, thinking more like a Machiavellian, added to the argument the prospect of usurpation by the incumbent- "Shut the Civil road to Glory and he may be compelled to seek it by the sword"- and defiance of law by the electorate_- "In moments of pressing danger the tried abilities and established character of a favorite Magistrate will prevail over respect for the forms of the Constitution" (July 19, 2:53; also July 24, 2:104-05). Machiavelli also cautions against placing the public in a position of losing the state or breaking the law: "For when a like mode [i.e., concentrated power] is lacking in a republic, it is necessary either that it be ruined by observing the orders or that it break them so as not to be ruined" (D.1.34.3).

The principal powers of the executive branch included veto, pardon, appointment, treaties, and commander-in-chief. In most cases Morris pushed for full and exclusive exercise of these powers. He recommended an absolute veto in the executive, though largely for defensive

\footnotetext{
${ }^{48}$ Votes taken on June 2, July 17, July 24, July 26, and August 24 affirmed the Virginia Plan mode of electing the president. Shlomo Slonim attributes the enduring attractiveness of the plan to the advantages it conferred on small and southern states alike; and the carryover of these same advantages into the electoral college, plus that institution's neat balancing of national and confederal elements, is how he explains the final abandonment of the Virginia Plan mode ("The Electoral College at Philadelphia: The Evolution of an Ad Hoc Congress for the Selection of a President," Journal of American History 73 [June 1986], 55-56; see also Mintz, GM and the American Revolution, 195; Best, “Legislative Tyranny," 707).
} 
purposes, which was why he also supported involvement of the judiciary in a council of revision (August 7, 2:200; August 15, 2:299; July 21, 2:75-76, 78-79). He wanted the pardon power exercised by the executive alone, even in cases of treason, which some delegates thought "too great a trust" and an investment "peculiarly improper" (September 15, 2:626-27). He urged removal of the senate from a share of the appointment power (August 23, 2:389). At a moment in the Convention when the treaty-making power rested with the senate, he expressed his misgivings and proposed as an amendment that treaties be ratified by law, which perforce would require the concurrence of the president (August 23, 2:392-93), whom he later referred to, and in this same context, as "the general Guardian of the National interests" (September 7, 2:541). ${ }^{49}$ The power of commander-in-chief was discussed in connection with state militias — when they would fall under federal control, how they would be armed and disciplined, who would appoint their officers - and in connection with the legislature's power to "make war," which on the suggestion of Madison and Gerry was changed to "declare war," providing a clear instance of limited jurisdiction (August 23, 2:384-88; August 18, 2:329-33). Morris was not heard from on this last topic. ${ }^{50}$

To recap: Morris analyzed executive power using (whether deliberately or not) ${ }^{51}$ the Machiavellian concept of guardianship. But rather than confer this responsibility on one of the

\footnotetext{
${ }^{49}$ Jack N. Rakove remarks that Morris went further than other delegates in conceiving of the executive as the embodiment of "a coherent national interest" (Original Meanings: Politics and Ideas in the Making of the Constitution [New York: Knopf, 1996], 266).

${ }^{50}$ See Michael J. Klarman, The Framers' Coup: The Making of the United States Constitution (Oxford: Oxford University Press, 2016), 218-26.

${ }^{51}$ It perhaps bears repeating that the many similarities tying Morris and Machiavelli together do not add up to certain proof that Morris actually read Machiavelli, much less that Morris was making conscious, if unattributed, use
} 
social orders, as does Machiavelli when first raising the question, Morris designated the president the guardian of the people, the guardian of liberty, and finally the guardian of national interest. As such, the people's political involvement would be less direct and less constant than was the case with the Roman plebs. ${ }^{52}$ Morris' departure from doctrine was more apparent than real, however, because Machiavelli allows that in non-expansionary states, such as Sparta, the executive might perform the task of guarding for a populace that is quiescent. Did Morris see America as a nonexpansionary state (albeit an extensive one)? That was his hope, as indicated by a 1781 letter to John Jay, in which Morris recommended that the western territories remain a wilderness lest they become a separate country. ${ }^{53}$ The category of civil prince provided a still stronger point of congruence. The civil prince was an executive who made himself a friend of the people and adversary of the great. For Machiavelli-describing principalities, not republics-that

of Machiavelli's writings while speaking at the Convention. It could rather be that Morris instinctively thought as Machiavelli thought and gravitated toward Machiavelli's orbit without ever realizing it.

${ }^{52}$ Mansfield discerns a lessening of political involvement in Machiavelli's representation of the Roman plebs, whose reputed removal from the center of party competition Mansfield calls the "impartial regime." The impartial regime reorients politics toward acquisition and distribution and away from claims of justice, inherently partial; and it reduces the public's role to that of an electorate. Mansfield regards the impartial regime as Machiavelli's chief constitutional innovation, an improvement on the mixed regime of the ancients (Machiavelli's Virtue, 115-16). I differ with Mansfield on this point especially (Machiavelli's Romans, 204-07).

53 “The principles, which caused and which justify the present revolution, will cause and justify as many more, as time and circumstances may furnish occasion for. The question then resolves itself into this: shall we be bounded by a wilderness, or a rival nation? Reason says the former, and bids us pursue the path which leads to it. The blind avarice of dominion may propel us into another road, but it leads to ruin" (Sparks, Life of GM, 1:225). See also Morris' letter of November 25, 1803 to Henry W. Livingston (Farrand, Federal Convention, 3:401); Barlow, Selected Writings of GM, 351; and Swiggett, Extraordinary Mr. Morris, 120-21. 
relationship rests on shrewdness, timeliness, treachery, and gratitude; for Morris-describing republics - it rested on popular election. Additionally, Morris, like Machiavelli, sought energy in the executive, if not by an uno-solo dictator, jurisdictionally bound but otherwise omnipotent, then by a single president invested with specified powers exercised without constraints; and a short term of office lengthened by the prospect of reelection, providing surety against extraordinary extensions excused by emergencies.

\section{A Fickle, Inconstant, and Irregular Machiavellian}

In delegate Pierce's assessment, Morris was not all profundity and splendid elocution; for he could be as well a fickle, inconstant, and irregular person, never pursuing a single train of thought. The charge has some merit. At the Convention, Morris generally displayed a Machiavellian temperament_-presuming the worst of human beings — but he also, from time to time, revealed an optimistic, even idealistic, side to his personality. ${ }^{54}$ Morris once described himself "as a Representative of America" and of "the whole human race"; as a gentleman who could not "descend to think" that his Convention colleagues had "assembled to truck and bargain for [their] particular States," and who was confident that a "reasonable \& right" plan of government would be embraced by "all who have reasonable minds and sound intentions" (July 5, 1:529). When a southern delegate put these laudable sentiments to the test, speaking on behalf of purely sectional interests, Morris replied, "he [Morris] came here to form a compact for the good of America" (July 12, 1:593). And when another southerner objected to locating the new government in a fixed place, fearing that a temporary site (in New York City, where the Congress presently sat) would become the permanent site, Morris declared, "such a distrust is inconsistent with all

\footnotetext{
${ }^{54}$ Brookhiser, Gentleman Revolutionary, 28.
} 
Government" (August 11, 2:261). Morris the cynic suffered from occasional bouts of youthful idealism.

And like a youth, he could be absurdly impulsive. "Let us have no Government at all," he vented, if it were thought that national legislators could not be trusted to reapportion at their discretion (July 11, 1:583). He was similarly hasty in the matter of regional differences: "If [the North-South divide] be real, instead of attempting to blend incompatible things, let us at once take a friendly leave of each other" (July 13, 1:604). Morris was the first to countenance a partial union of the willing (May 30, 1:37).

Morris advised the Convention to protect forevermore the voting advantage of the Atlantic states against untrustworthy westerners with different interests, while simultaneously urging southerners to trust that northern majorities in the national legislature would reapportion in the absence of a constitutional duty. Madison noted the inconsistency: "At the same time that he recommended this implicit confidence to the Southern States in the Northern Majority, he was still more zealous in exhorting all to a jealousy of a Western Majority. To reconcile the gentleman with himself, it must be imagined that he determined the human character by the points of the compass." Mason then joined the attack, explaining that confidence in the people's representatives required that they actually be representative, which in turn required reapportionment reflective of population shifts (July 11, 1:583, 584, 586). 


\section{It was in defense of the principle of legislative discretion that Morris exposed himself to} this ridicule and rebuke. ${ }^{55}$ He failed to preserve discretion as applied to reapportionment. ${ }^{56}$ But as applied to western states, he scored a sly and subtle victory, worthy of a Machiavellian fox.

\footnotetext{
55 The case for discretion rests on two assumptions: that human judgment, operating in the present, is wiser than rules enacted in the past; and that human beings, unrestrained by rules, are trustworthy. Morris did not generally share these assumptions (e.g., Farrand, Federal Convention, 3:418; Barlow, Selected Writings of GM, 429), but he championed discretion nonetheless. Either Morris was being incoherent, as Madison implied, or Morris was executing a complicated rhetorical strategy risky to his reputation (like Junius Brutus simulating craziness in order to topple the Tarquins and institute a republic! [D.3.2]). Possibly it was some of both; possibly his declarations of idealism and his youthful impetuosity were also some of both.

${ }^{56}$ On July 5, the Committee on Senate Suffrage presented its multi-part compromise, the primary provisions of which called for proportional representation of persons in the lower house, set at 1 representative per 40,000 inhabitants, and equal representation of states in the upper house. To the first provision, Morris offered two objections: that as "property was the main object of Society ... it ought to be one measure of the influence due to those who were to be affected by the Government"; and that "the rule of representation ought to be so fixed as to secure to the Atlantic States a prevalence in the National Councils" (1:533). Morris' own position, offered the next day, was that the legislature should be free "to provide for changes in the relative importance of the States, and for the case of new States" (July 6, 1:540). Relative importance would allow wealth as well as numbers to be taken into account. Numbers could be known with certainty once a census was conducted, and several delegates from the South, expecting population increases in their states, insisted that the census be mandatory. Wealth, by contrast, could only be surmised. If it were to factor in reapportionment, approximate judgments would have to suffice. Morris fought the census tenaciously, appearing foolish to some colleagues (and many readers), because mixed-regime theory required that the social orders be empowered to defend themselves (Sparks, Life of GM, 2:247; 3:336). "Property ought to have its weight, but not all the weight," he stated (July 10, 1:567). Likewise, Lockean theory enshrined the importance of property, which Morris put ahead of life and liberty (July 5, 1:533). In the end, Wilson settled the matter, arguing that wealth correlated with population and that the representation of population would accomplish the representation of wealth (July 13, 1:605-06).
} 
Morris opposed the easy admission and equal treatment of western states. He rated westerners "back members" from the "remote wilderness," lacking in political talent and "always most averse to the best measures" (July 11, 1:583). Unenlightened ploughmen were they, who could hardly complain of discriminations, such as under-representation, because they "would previously know the conditions on which they would possess their lands" (July 5, 1:534). ${ }^{57}$ More alarming than their uncouth backwardness was their supposed proclivity to draw the country into wars - e.g., with Spain over navigation rights on the Mississippi-that the maritime states would have to fight at sea (July 5, 1:533; July 13, 1:604). ${ }^{58}$ Also, the commercial interests of the North would suffer oppression if power shifted to the agrarian West (July 11, 1:583; July 13, 1:604). Like many northerner delegates, Morris worried that western migration would depopulate the North, but not the South, costing the North its majority status in the union. He foresaw an inevitable conjoining of southern and western interests against the interests of the mid-Atlantic and northerner states: "It has been said that N.C. S.C., and Georgia only will in a little time have a majority of the people of America. They must in that case include the great interior Country, and every thing was to be apprehended from their getting the power into their hands" (July 13, 1:604-05). Not remarked on the occasion, but no doubt in the back of Morris' mind, was the prospect of slavery's expansion into the West. ${ }^{59}$ Hence Morris wished to keep the country's

\footnotetext{
${ }^{57}$ Machiavelli explains the discriminations practiced against late-arriving Venetians in very nearly the same terms

${ }^{58}$ Roosevelt confirms Morris' prophecy, claiming that the War of 1812 was caused by the South and the West, while most of the war's cost was borne by the East (Gouverneur Morris, 148). See also Mintz (GM and the American Revolution, 187).

${ }^{59}$ Kaufman accounts for Morris’ opposition to western expansion mainly in light of Morris’ opposition to slavery (“Constitutional Views of GM,” 392, 404-29).
} (D.1.6.1). 
political center of gravity firmly in the East, even while acknowledging that western settlement could not be prevented (August 29, 2:454).

Article XVII of the Committee of Detail report addressed the issue of new states. Morris moved that the provision for admission "on the same terms with the original States" be omitted on grounds that "to bind down the Legislature" was improper (August 29, 2:454). When he tried for discriminations in mid-July, he was roughed up in debate, especially by Wilson, who observed that such a policy would replicate the oppression visited on American colonies by the British Parliament, and that the certain result would be, as before, separation and independence (July 13, 1:605). This time the Convention became entangled in questions about the voluntary, or involuntary, disjunction of territories from their home states. Over the course of two days (August 29-30), the Convention took some eleven votes respecting the motion by Morris to omit, his substitute proposal, other substitutes to his substitute, and related matters. Morris won all eleven votes, concluding with a 10-1 adoption of his lightly amended, substitute proposal. Throughout it all, no one contested the removal of "same terms" treatment of western states, even though one delegate explained, just before the first and most consequential vote, that "existing small states enjoy equality now" because they are already in the union, and that "this reason is not applicable to new Western states" (August 29, 2:454). For reasons not at all clear but likely having to do with backstage maneuverings orchestrated by Morris,${ }^{60}$ the Convention discarded its preference for no

\footnotetext{
${ }^{60}$ Some years later, in a letter to Henry W. Livingston (December 4, 1803), Morris reflected on the success of his substitute proposal and of his discrimination strategy practiced at the Convention: "In wording the third section of the fourth Article [of the Constitution], I went as far as circumstances would permit to establish the exclusion [of new states from territories not possessed at the time of Constitution]. Candor obliges me to add my belief that had it been more pointedly expressed, a strong opposition would have been made" (Farrand, Federal Convention, 3:404).
} 
discriminations and voted to leave equal or unequal treatment of new states to the discretion of the legislature. ${ }^{61}$ A small victory was this, perhaps never to be acted upon, but one that showed Morris, the foxy Machiavellian, striving to preserve his vision of America.

\section{Conclusion}

It is commonly observed that Gouverneur Morris spoke at the Convention more often than any other delegate despite missing a month of the proceedings. By and large his comments were extensive, substantive, and provocative. Sometimes they were consequential. While the paper's purpose is not to delineate all that Morris stood for and accomplished in Philadelphia, a quick mention of what arguably were his three most important contributions may be a good way to end.

Morris paired representation with taxation and by so doing disrupted the regional battlelines that were forming around the issue of slavery (July 12, 1:592). The South would pay for its slaves in the same proportion that its slaves were counted in the representation. A large, multifaceted bargain was the eventual result, one part of which was a population-based direct tax that sat in the Constitution until removed by the Sixteenth Amendment. Meanwhile, Morris delivered the Convention's most eloquent and stinging denunciation of slavery and the slave trade (August $8,2: 222)$.

As a member of the Committee on Postponed Matters, Morris explained and defended an unsanctioned mode of electing the president that discarded the Convention's often-affirmed

${ }^{61}$ See Akhil Reed Amar, America's Constitution: A Biography (New York: Random House, 2006), 274-75; Kirschke, GM: Author, Statesman, 194. Might legislative discretion include suspension of the 1 per 40,000 apportionment requirement (changed to 1 per 30,000)? Possibly, since this requirement was once challenged, at the time of the Missouri Compromise, by some northerners who wanted the three-fifths counting of slaves denied to new, western states (Farrand, Federal Convention, 3:430; Klarman, Framers' Coup, 277). 
preference for election by the national legislature-namely, the electoral college (September 4, 5, $6 ; 2: 500,512,523-24)$. Wilson was the main architect of this alternate mode, whose elements appeared piecemeal throughout the course of debate; but it was Morris, in committee, who must have assembled the elements and refined the plan.

Finally, Morris composed the language of the Constitution, arranged the document into Articles and Sections, and supplied the Preamble. ${ }^{62}$ "We the People of the United States, in Order to form a more perfect Union, establish Justice," and so forth, is a Morris legacy.

\footnotetext{
${ }^{62}$ Letter to Jared Sparks, April 8, 1831 (Farrand, Federal Convention, 3:499); also Morris' letter to Timothy
} Pickering, December 22, 1814 (Farrand, Federal Convention, 3:420). 